\title{
Sample Preparation Considerations for X-ray EDS Analysis in the Physical Sciences
}

\author{
Scott D. Walck
}

Bowhead Science and Technology, Army Research Laboratory, Aberdeen Proving Ground, MD USA

The use of X-ray Energy Dispersive Spectroscopy (X EDS) in an electron $m$ icroscope is perhaps the most utilized technique for the $\mathrm{m}$ icroanalysis of $\mathrm{m}$ aterials. X-ray detector $\mathrm{s}$ can be found on scanning electron microscopes (SEM), dual bea $\mathrm{m}$ focused i on beam (FIB) sys tems, and tr ansmission electron microscopes (TEM) for both the physical and biological sciences. With respect to using it for analysis, there are two basic assumptions that apply, 1) the volume analyzed is homogeneous and 2) the e xiting surface for the X-rays is flat. The one exceptio $n$ to this is thin film on substrate an alysis, but it is still assumed that the f ilm layers and substrate are homogeneous and the sam ple is flat. Of course, additionally for analysis in the TEM, the sample must be thinned to electron transparency.

There are numerous methods for sample preparation for SEM and TEM. In the past, preparing a sample for XEDS in the SEM would be relatively straight forward; it would entail $\mathrm{m}$ echanically polishing the sample flat, coating it with car bon if it were non-conduc tive, placing it under an electron beam with sufficient overvoltage, and analyzi ng it. However, with the advent of the other characterization techniques in the SEM (or FIB), such as EBSD , STEM, t-EBSD, 3D tomography, Spectrum Imaging, etc., the sample may also need to be prepared with that technique in mind as well. Because of this, the same processes that have been traditionally used for TEM sample preparation might also be $u$ sed for samples that are analyzed in the SEM by XEDS. W ith this in $\mathrm{m}$ ind, the issues associated with these sample preparation techniques that lead to artifacts will be discussed. It would be prohibitive to discuss specific details of these different te chniques and how they relate to XEDS analysis to cover all aspects. Instead, the goal of this paper is to discuss how artifacts from sample preparation may affect the analysis of the sample and how they relate to the two primary assumptions. Table 1 lists the sam ple preparation techniques to be discussed with a short description of the $\mathrm{m}$ icroscopy utility and potential a rtifacts affecting XEDS analysis. The effects th at some of these artifacts would have on XEDS analysis are obvious, but others $\mathrm{m}$ ay be $\mathrm{m}$ ore subtle. For ex ample, why would plasm a cleaning, a necessary procedure for many samples to prevent hydrocarbon c ontamination, be listed as a potential source for contamination? Each artifact lis ted can be a ssociated with one of th e two basic assumptions. Topography changes, by differential sputtering or pol ishing violate the flatne ss assumption and will affect the path length of X-rays and thereby aff ect the absorption and fluorescence. Precipitation, contamination, re-deposition, oxidation violate the homogeneous assum ption and m odify the composition of the analyzed volume. The degree to which the specific sample preparation artifact has on the XEDS analysis due to the departure from these assumptions is strongly dependent on the analytical instrument. The key to good $\mathrm{m}$ icroscopy is sample preparation with a minimum of artifacts introduced. Although, in general, th e sample preparation requirements for good analytical results with XEDS are less stringent, the microscopist should be aware of the potential for artifacts introduced during preparation that could influence the analytical results. 
Table 1

Sample Preparation Artifacts

\begin{tabular}{|c|c|c|}
\hline Preparation Technique & Microscopy Technique & Artifact \\
\hline $\begin{array}{l}\text { Mechanical Polishing (e.g. } \\
\text { lapping, Tripod Polishing, } \\
\text { dimpling) }\end{array}$ & $\begin{array}{l}\text { SEM: XEDS analysis, cross section } \\
\text { TEM: plan view, cross section }\end{array}$ & $\begin{array}{l}\text { Smearing, differential polishing, } \\
\text { edge rounding, scratched surfaces, } \\
\text { embedded abrasives }\end{array}$ \\
\hline Ion Milling & $\begin{array}{l}\text { SEM: Ion Polishing for EBSD, slope } \\
\text { cutting, Ion etching for phase and } \\
\text { grain boundary contrast } \\
\text { enhancement } \\
\text { FIB: 3D Tomography (XEDS, } \\
\text { EBSD), Cross section } \\
\text { TEM: Final thinning, FIB cleaning }\end{array}$ & $\begin{array}{l}\text { SEM: preferential sputtering } \\
\text { leading to topography } \\
\text { FIB: amorphization, curtaining, Ga } \\
\text { incorporation, microstructure } \\
\text { changes } \\
\text { TEM: Topography, preferential } \\
\text { sputtering leading to thickness } \\
\text { variations within/between phases, } \\
\text { chemical changes, phase changes, } \\
\text { contamination, amorphization, } \\
\text { hydride formation, re-deposition }\end{array}$ \\
\hline $\begin{array}{l}\text { Electropolishing/Chemical } \\
\text { Polishing }\end{array}$ & $\begin{array}{l}\text { SEM: Etching for phase and grain } \\
\text { boundary contrast enhancement } \\
\text { TEM: Final thinning }\end{array}$ & $\begin{array}{l}\text { SEM: Differential polishing leading } \\
\text { to topography, } \\
\text { TEM: Differential polishing leading } \\
\text { to variations in thickness or phase } \\
\text { dropouts, surface re-deposition } \\
\text { leading to thickness composition } \\
\text { variations with thickness, } \\
\text { hydrocarbon contamination }\end{array}$ \\
\hline Ultramicrotomy & $\begin{array}{l}\text { SEM: Serial block face imaging and } \\
\text { 3D Tomography } \\
\text { TEM: Final thinning }\end{array}$ & $\begin{array}{l}\text { SEM: Surface topography } \\
\text { TEM: ?? }\end{array}$ \\
\hline Cleave/Fracture & $\begin{array}{l}\text { SEM: Cross section } \\
\text { TEM: Plan view, Cross section, } \\
\text { slivers }\end{array}$ & $\begin{array}{l}\text { SEM: Particle Geometry } \\
\text { TEM: ?? }\end{array}$ \\
\hline Crushing/Grinding & $\begin{array}{l}\text { SEM: N/A } \\
\text { TEM: Final thinning, Standards }\end{array}$ & $\begin{array}{l}\text { SEM: Particle geometry } \\
\text { TEM: Particle geometry that leads } \\
\text { to variation in thickness for } \\
\text { standards }\end{array}$ \\
\hline $\begin{array}{l}\text { Plasma } \\
\text { Cleaning/Trimming }\end{array}$ & $\begin{array}{l}\text { SEM: Cleaning hydrocarbon } \\
\text { contamination } \\
\text { TEM: Cleaning hydrocarbon } \\
\text { contamination, removing amorphous } \\
\text { surface layers }\end{array}$ & $\begin{array}{l}\text { SEM: Oxidation, Contamination } \\
\text { TEM: Oxidation, Contamination, } \\
\text { re-deposition }\end{array}$ \\
\hline
\end{tabular}

